\title{
Reconstruction of the 1874 Santa Tecla's rainstorm in Western Catalonia (NE Spain) from flood marks and historical accounts
}

\author{
J. C. Balasch ${ }^{1}$, J. L. Ruiz-Bellet ${ }^{1}$, J. Tuset ${ }^{1,2}$, and J. Martín de Oliva ${ }^{1}$ \\ ${ }^{1}$ Department of Environment and Soil Sciences, University of Lleida, Spain \\ ${ }^{2}$ Forest Technology Centre of Catalonia, Solsona, Spain
}

Received: 21 July 2010 - Revised: 29 October 2010 - Accepted: 4 November 2010 - Published: 19 November 2010

\begin{abstract}
The Santa Tecla flash flood, a very heavy event occurred in western Catalonia (NE Spain) in 1874, was reconstructed with hydraulic and hydrological modelling tools in three basins. The hydrograph obtained in a first step and the basin soil moisture information ultimately allowed the estimation of the range of the rainstorm magnitude which caused the flash flood. The reconstruction of historical floods has proved useful to improve the flood probability analysis, especially in ungauged basins.
\end{abstract}

\section{Introduction}

At least since the seventeenth century, the western area of Catalonia (NE Spain) has been affected by several heavy flash floods, as the local chronicles bear witness to. This kind of flash floods is caused by heavy torrential rainstorms, generally fed by eastern autumn winds, and hit, primarily, steep, small, torrential basins (a few hundreds of $\mathrm{km}^{2}$ ), flowing either westward to the Segre River or eastward to the Mediterranean.

Among all these events, Santa Tecla's rainstorm stands out because of its capacity for destruction; it happened during the night between 22nd and 23rd September 1874, Saint Tecla's day, after which it was named.

According to historical documentary records (newspapers and others), this rainstorm affected especially an area of about $3000 \mathrm{~km}^{2}$ delimited by the Montsant mountains to the south, the town of Igualada to the east, and the eastern part of the Catalan Central Depression to the west and north (Fig. 1); more specifically, the most affected catchments were: Llobregós, Sió, Ondara, Corb, Femosa and Set in the Segre River basin, and Francolí, Siurana, Rieres del Baix Camp, Gaià,

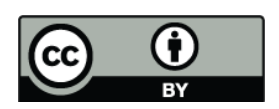

Correspondence to: J. C. Balasch (cbalasch@macs.udl.cat)
Foix, Rieres del Garraf and Anoia in the Mediterranean-ward basins. In the rest of Catalonia, it rained abundantly as well, though less than in the above-cited area (Iglesias, 1971).

Since the rainstorm began around midnight and affected small, quick-response catchments - with lag-times of $4 \mathrm{~h}$ or less -, the damages along the rivers were catastrophic: 570 direct deaths (310 of which in Ondara and Corb basins only) and about 700 collapsed dwellings. In addition, the salvage and reconstruction tasks were hampered because of the contemporary 3rd Carlist War.

Unfortunately, before early twentieth century, there were almost no rain gauging stations in Catalonia (only in Barcelona, which lies far from the studied area); likewise, stream gauges began to operate only in 1913 and solely on main rivers. Actually, the earliest 24-h maximum rainfall series in the study area, the one of Tàrrega (in the Ondara basin), starts in 1915 . Therefore, there are neither rainfall nor flow data of Santa Tecla's rainfall.

Despite the lack of gauging records of the event, the fortunate survival of a number of flood marks - along with written accounts, source of crucial data such as the rainstorm duration and the moment of the peak flow arrival (Salvadó, 1875) or the soil moisture condition prior to the event (Pleyán de Porta, 1945) - allowed, through the iterative backwards application of a hydraulic and a hydrological model, the reconstruction of Santa Tecla's rainstorm and the floods that it caused.

Indeed, the objective of this study was the estimation of the principal meteorological and hydrological magnitudes during Santa Tecla's rainstorm in three catchments in the Segre River basin (Sió, Ondara, Corb) and, more specifically, the quantification of the most likely spatial distribution of the rain.

Actually, the reconstruction of historical floods can help to improve the forecasting ability - and thus, the prevention capacity - which is presently based, in most of the cases, on very short gauging data series. Besides, this kind of research

Published by Copernicus Publications on behalf of the European Geosciences Union. 


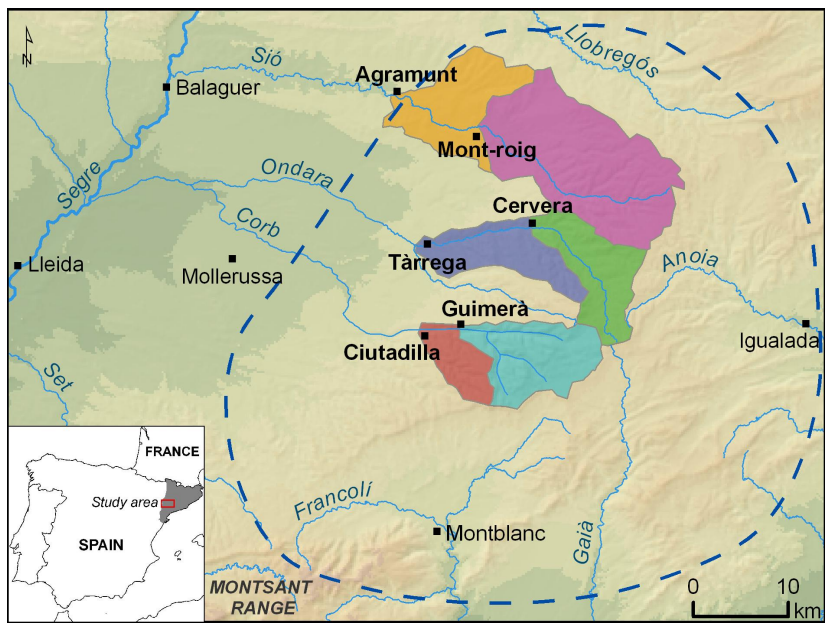

Fig. 1. Map of the area in Western Catalonia (NE Spain) affected by Santa Tecla's rainstorm in 1874 (blue dashed line), with the three river basins tributaries of the Segre River and the six towns considered in the reconstruction of the event.

enables to assess the long-term evolution of these rare events with regard to human impacts on basins and streams; this is all the more valid in the Mediterranean basin, an area with an extremely changing climate and under a heavy human pressure.

\section{Study area}

The study area spreads over three catchments in the Segre River basin, which are, from north to south: Sió, Ondara and Corb (Fig. 1). For each catchment, two different outfalls, corresponding to the places with flood marks available, were considered resulting in six sub-basins: Mont-roig and Agramunt (Sió); Cervera and Tàrrega (Ondara); Guimerà and Ciutadilla (Corb); actually, the modelling was undertaken separately at each one of the six sub-basins.

These three basins total some $600 \mathrm{~km}^{2}$, have a westward orientation and their headwaters lie on the Catalan Central Depression's monoclinal relieves, between 700 and $900 \mathrm{~m}$ (Llena, Tallat and Montmaneu ranges); the main land use is dryland cereal farming, established in Roman times. Table 1 gathers some morphological and hydrographical characteristics of these basins.

The three rivers are left-side tributaries of the downstream stretch of the Segre River; nevertheless, the Ondara and Corb rivers flow out into large alluvial fans, before reaching the Segre. All of them have scarce flows all year round, with a high-water period around May and long low-water periods, but, due to irrigation, they never dry up. In any case, autumn overflowing flash floods are typical, occurring about three or four times per century (Coma, 1990).

Certainly, severe rainstorms are not rare; this can be partially explained by the regional relief, which triggers storms in two ways: stopping weather fronts arriving from the

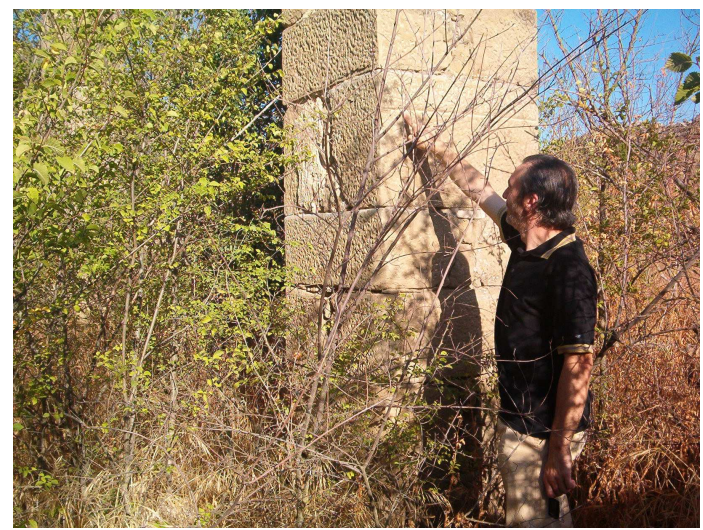

Fig. 2. Flood mark preserved in a column inside Serra's watermill remains at Mont-roig by the Sió River.

Mediterranean Sea and contributing to the development of convective phenomena during summer and early autumn. All this results in two rainfall gradients: a northward one and an altitudinal one.

\subsection{The Sió River basin}

The Sió River basin is the northernmost and the largest of the three. A flow gauging station at the outlet (Balaguer, EA182) operated from 1965 to 1992 and recorded an average daily mean flow of $0.8 \mathrm{~m}^{3} \mathrm{~s}^{-1}$ and a peak flow of $16 \mathrm{~m}^{3} \mathrm{~s}^{-1}$.

In this basin, Santa Tecla's rainstorm caused no casualties; nevertheless, it destroyed Urgell Canal's aqueduct at Agramunt and devastated every orchard on the floodplain from Guissona to Balaguer. Two flood marks of this event have survived: one at Serra's watermill, $700 \mathrm{~m} \mathrm{NW}$ Mont-roig (Fig. 2), and one at Agramunt, by the medieval bridge.

\subsection{The Ondara River basin}

This is the central basin of the three and the one with the largest percent of farming land use. There have never been any flow gauging station on the Ondara River; nevertheless, through water resources modelling, its average flow has been estimated at $0.5 \mathrm{~m}^{3} \mathrm{~s}^{-1}$ (CHE, 1996).

Santa Tecla's effects were the most destructive at Tàrrega: 150 dead and 300 damaged buildings; nevertheless (or maybe because of this), it is the area with more available information about the event: three marks scattered over the old town pinpoint the highest water level reached by that flood (Tuset, 2007; Balasch et al., 2010) (Fig. 3). In addition, there is an account of the event by a citizen of Tàrrega (Salvadó, 1875), which details the kind of clouds and their location, the rainstorm starting and ending times, and the peak flow arrival's time. Furthermore, recent archaeological surveys have revealed a three-metre infilling in the riverbed, a crucial piece of information for the reconstruction of the former fluvial morphology (Fig. 4). 
Table 1. Morphological and hydrographical characteristics of Sió, Ondara and Corb basins.

\begin{tabular}{lcccccc}
\hline & \multicolumn{2}{c}{ Sió } & \multicolumn{2}{c}{ Ondara } & \multicolumn{2}{c}{ Corb } \\
& Mont-roig & Agramunt & Cervera & Tàrrega & Guimerà & Ciutadilla \\
\hline Area $\left(\mathrm{km}^{2}\right)$ & 219 & 314 & 86 & 150 & 91 & 123 \\
Main stream length $(\mathrm{km})$ & 24 & 35 & 17 & 28.6 & 15 & 19.6 \\
Main stream slope $(\%)$ & 1.4 & 1.2 & 1.7 & 1.4 & 1.7 & 2.2 \\
Max/min heigth (m a.s.1.) & $745-400$ & $745-335$ & $804-460$ & $804-356$ & $890-500$ & $890-450$ \\
\hline
\end{tabular}

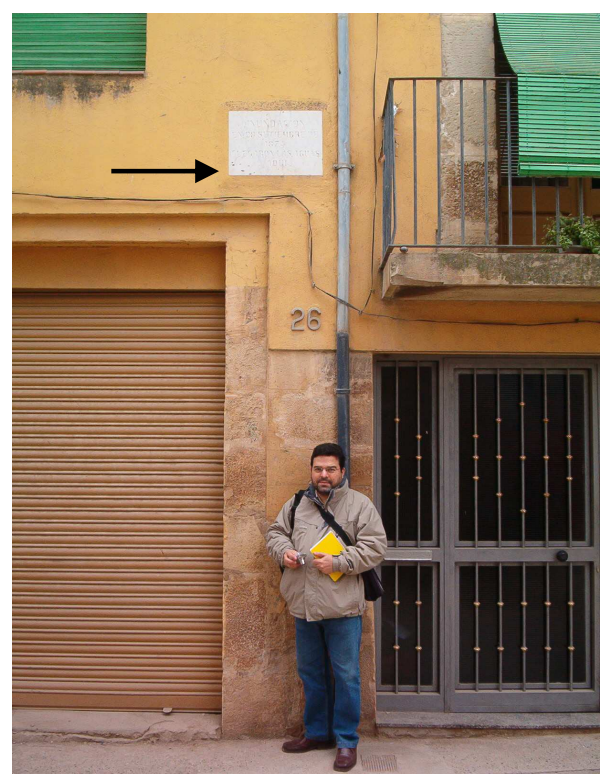

Fig. 3. Epigraphic limnimark or flood mark at Sant Agustí street in Tàrrega, pointing the maximum water level reached by the Santa Tecla's flood.

At Cervera, the flood mark is at Grau's watermill (Tuset, 2007), which, according to the chronicles, the high waters kept isolated for one week. The chronicles state as well the peak flow arrival's time to that site (Xuclà, 1977).

\subsection{The Corb River basin}

The Corb basin is the southernmost and the most forested of the three, especially in the headwaters. A flow gauging station operated on the Corb River at its outlet (Vilanova de la Barca, EA183) from 1965 to 1992; it measured an average daily mean flow of $0.9 \mathrm{~m}^{3} \mathrm{~s}^{-1}$ and a peak flow of $48 \mathrm{~m}^{3} \mathrm{~s}^{-1}$.

There are two Santa Tecla's flood marks along the Corb, both in the central stretch of the river, a narrow V-shaped valley: one at Guimerà, where the flood killed 35 people and swept away 96 buildings, and one at Ciutadilla, at Hostal del Teuler (Martín de Oliva, 2005) (Fig. 5).

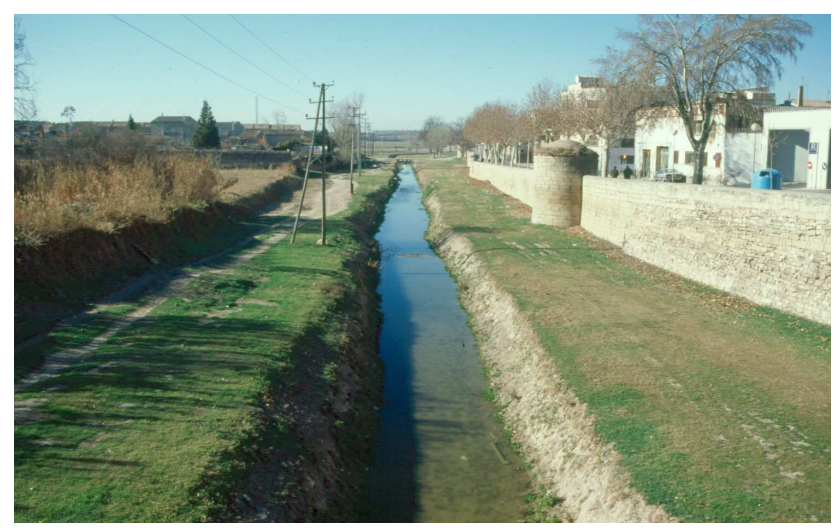

Fig. 4. The Ondara River at Tàrrega; 1874's river bed was three metres below the current thalweg.

\section{Methodology}

The event reconstruction methodology - put in practice separately at six modelling points: two in each one of the three basins - had two stages: the hydraulic modelling and the hydrological modelling (Fig. 6). Afterwards, a sensitivity analysis for each one of the two modelling stages was implemented.

The objective of the first stage - the hydraulic reconstruction - was the estimation of the peak flow through the iterative backwards application of a hydraulic model. The input data were: a digital terrain model; several cross sections, (Figs. 7 and 8); the cross-sections' roughness coefficients; the channel slope; and a tentative peak flow. The process was iterative, trying different tentative peak flows until the modelled maximum water level and the actual one - known through the flood marks - were close enough (i.e. less than $1 \mathrm{~cm}$ apart); and it was backwards because the peak flow was the unknown quantity, instead of being, as usual, an input of the model. Therefore, some authors call this method "retromodelling" (Remo and Pinter, 2007). The model applied was a unidimensional one in sub-critical permanent conditions (HEC-RAS v. 4.0; USACE, 2008). 
Table 2. Input data used in the hydraulic and in the hydrological modelling.

\begin{tabular}{|c|c|c|c|c|c|c|c|}
\hline & & \multicolumn{2}{|c|}{ Sió } & \multicolumn{2}{|c|}{ Ondara } & \multicolumn{2}{|c|}{ Corb } \\
\hline & & Mont-roig & Agramunt & Cervera & Tàrrega & Guimerà & Ciutadilla \\
\hline \multicolumn{2}{|c|}{$\begin{array}{l}\text { Flood mark's height above } \\
1874 \text { river bed }(\mathrm{m})\end{array}$} & 5.18 & 4.88 & 5.10 & 8.84 & 7.72 & 10.16 \\
\hline $\begin{array}{l}\text { Cross } \\
\text { sections }\end{array}$ & $\begin{array}{c}\text { Type } \\
\text { Number } \\
\text { Spacing }(\mathrm{m})\end{array}$ & $\begin{array}{l}\text { Rural } \\
10 \\
20-30\end{array}$ & $\begin{array}{l}\text { Urban } \\
108 \\
20-30\end{array}$ & $\begin{array}{l}\text { Rural } \\
17 \\
60-80\end{array}$ & $\begin{array}{l}\text { Mixed } \\
23 \\
40-50\end{array}$ & $\begin{array}{l}\text { Urban } \\
50 \\
20-30\end{array}$ & $\begin{array}{c}\text { Rural } \\
14 \\
40-50\end{array}$ \\
\hline $\begin{array}{l}\text { Roughness } \\
\text { coefficients }\end{array}$ & $\begin{array}{c}\text { River bed } \\
\text { River banks } \\
\text { Rural floodplain } \\
\text { Urban floodplain }\end{array}$ & $\begin{array}{c}0.028 \\
0.085 \\
0.04 \\
-\end{array}$ & $\begin{array}{c}0.04 \\
0.065 \\
- \\
0.08\end{array}$ & $\begin{array}{c}0.035 \\
- \\
0.03 \\
-\end{array}$ & $\begin{array}{c}0.035 \\
- \\
0.04 \\
0.1\end{array}$ & $\begin{array}{c}0.073 \\
- \\
- \\
0.099\end{array}$ & $\begin{array}{c}0.073 \\
- \\
0.104 \\
-\end{array}$ \\
\hline $\begin{array}{l}\text { Channel slop } \\
\text { Rainstorm d } \\
\text { Antecedent s } \\
\text { Curve Numb }\end{array}$ & $\begin{array}{l}\mathrm{n} / \mathrm{m}) \\
\text { ion (h) } \\
\text { moisture } \\
\text { SCS) }\end{array}$ & $\begin{array}{c}0.005 \\
8 \\
\text { III } \\
85\end{array}$ & $\begin{array}{l}- \\
- \\
- \\
-\end{array}$ & $\begin{array}{c}0.002 \\
8 \\
\text { III } \\
86\end{array}$ & $\begin{array}{c}0.0045 \\
8 \\
\text { III } \\
85\end{array}$ & $\begin{array}{c}0.002 \\
6 \\
\text { III } \\
85\end{array}$ & $\begin{array}{c}0.009 \\
6 \\
\text { III } \\
84\end{array}$ \\
\hline
\end{tabular}

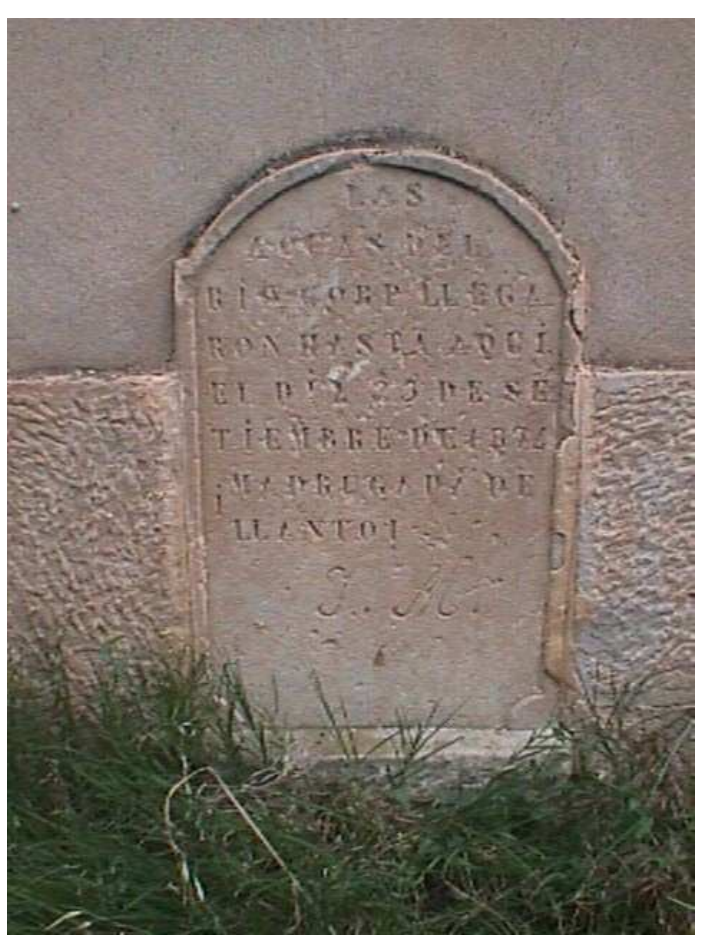

Fig. 5. Epigraphic flood mark of Santa Tecla in the Corb River at the base of a wall of Hostal del Teuler at Ciutadilla.

Thus, the hydraulic modelling required, at each one of the six studied points:

1. The flood mark data verification - through Bayliss and Reed's methodology (2001) - and the topographic measurement of the flood marks
2. The reconstruction of 1874 's river bed and floodplain morphology, which led to a digital terrain model and, ultimately, to the cross sections' selection and to the measurement of the river bed slope

3. The estimation of roughness coefficients for each segment of the cross sections (river bed, river banks, and urban and rural floodplains)

The second stage was the hydrological modelling, the objective of which was the reconstruction of the event hyetograph. The process was, once again, iterative and backwards, since the unknown quantity - rainfall - was an input instead of an output of the model. Thus, from a tentative hyetograph constructed from the historical descriptions of the event, the basin characteristics (soil type, land use and cover) and the antecedent soil moisture, the runoff or effective rainfall was calculated using the Soil Conservation Service's Curve Number method (SCS, 1985). Then, the Synthetic Unit Hydrograph transfer function and a wave propagation method (Muskingum-Cunge) were successively applied to this runoff value to obtain a convoluted and routed hydrograph. This process was repeated with a new tentative hyetograph until the peak flow of the resulting hydrograph was close enough to the one found in the first stage, that is, when their relative difference was less than $1 \%$ (Fig. 6). The software applied in this stage was HEC-HMS v. 3.3 (USACE, 2008), which uses a lumped rainfall-runoff model.

A lot of data was drawn from historical accounts; for example, an historical description of the event (Pleyán de Porta, 1945) states that the soil was at field capacity due to a generous rain just five days before Santa Tecla's rainstorm, in 18th September 1874. This circumstance was crucial in the hydrological modelling, because it led to choose a saturated-soil 


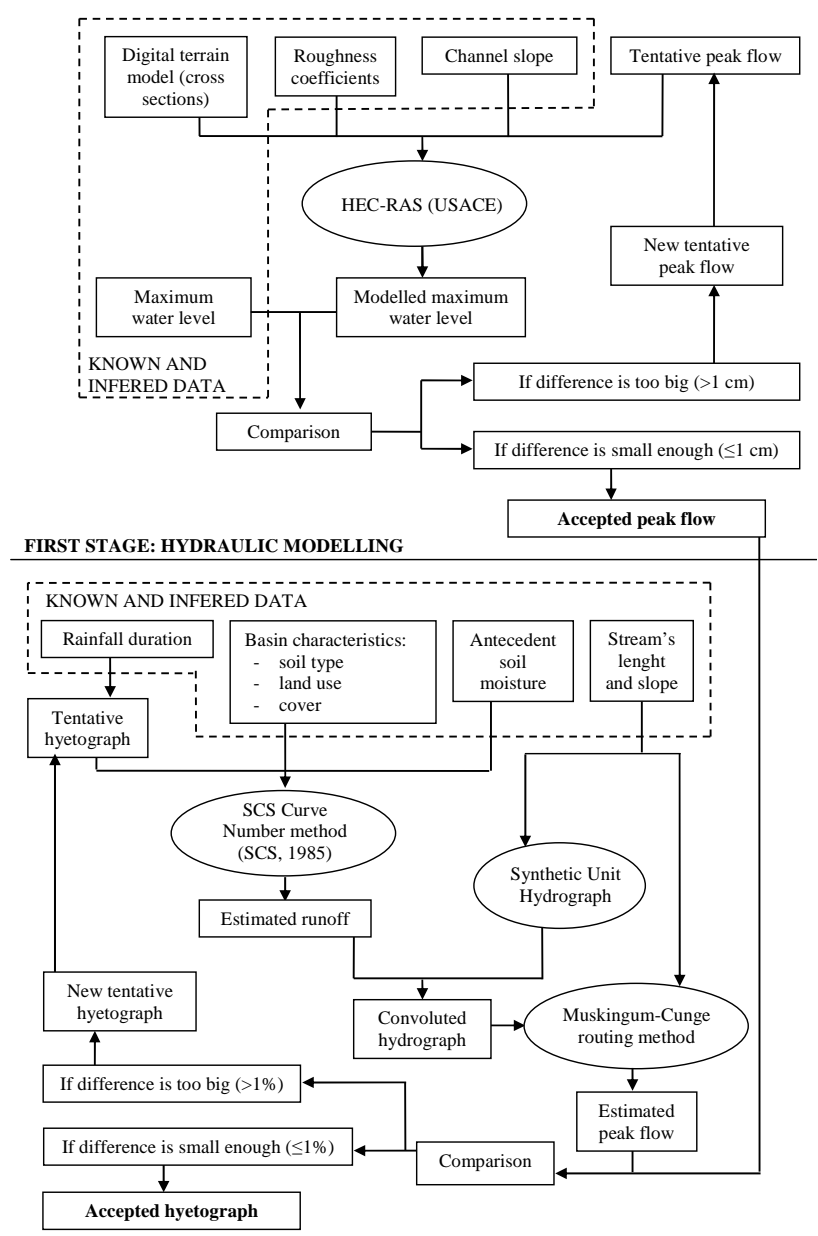

SECOND STAGE: HYDROLOGICAL MODELLING

Fig. 6. Methodological procedure for the calculation of the event's peak flow and hyetograph.

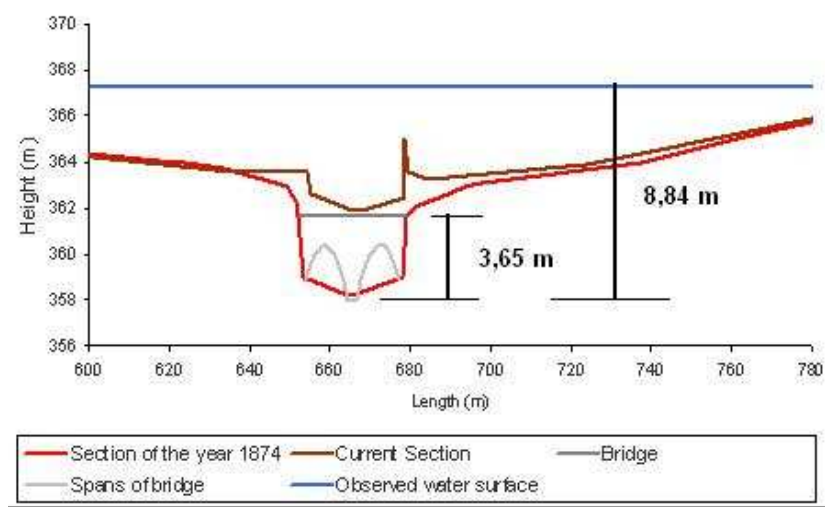

Fig. 7. Present-day (brown line) and 1874 (red line) cross-sections of the Ondara River at Sant Agustí Bridge (and the eponymous street), with the indication of the maximum water level (blue line) reached by the Santa Tecla flood.

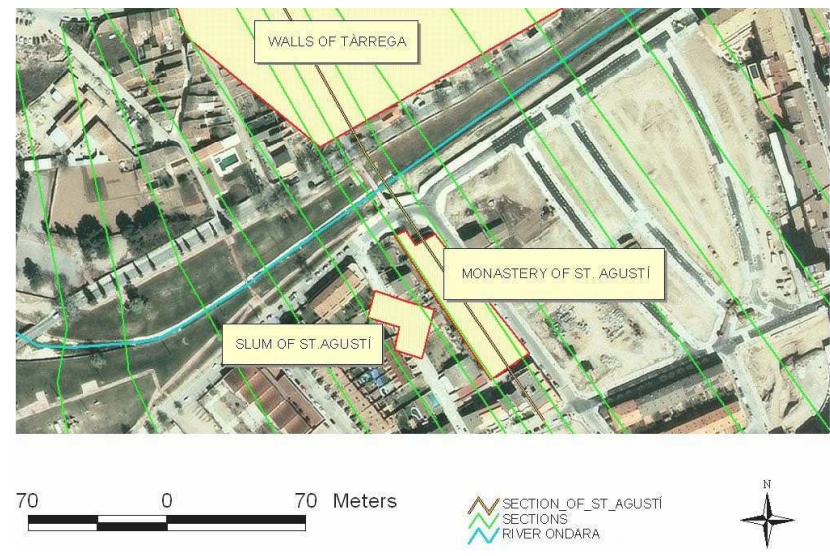

Fig. 8. Aerial photograph of the Ondara river channel (blue line) at Tàrrega with the location of the Sant Agustí Bridge, cross section (brown line) and the rest of cross sections (green lines) used in the hydraulic modelling. This figure shows as well the alleged location of the external walls of the city and the disappeared Sant Agustí monastery and nearby buildings according to the archaeological remains.

condition (condition III) in the Curve Number method. Likewise, other historical sources furnished the starting and ending times of the rainstorm: around 22:00 and 06:00, respectively (Iglesies, 1971; Salvadó, 1875).

Table 2 gathers the input data used the hydraulic and the hydrological modelling, respectively.

Once the hydraulic and the hydrological modelling were done, their robustness was assessed through sensitivity analyses.

More precisely, in the hydraulic model analysis, the effect of a variation in the maximum water level on the peak flow was quantified. In order to do this, at each studied crosssection, the hydraulic model was applied several times, the input data being variations of the peak flow actually found $\left(\mathrm{Q}_{p}\right)$ and the output being the peak water levels due to each one of these peak flow variations, which were $\mathrm{Q}_{p} \pm 1 \%$, $\mathrm{Q}_{p} \pm 2 \%, \mathrm{Q}_{p} \pm 5 \%, \mathrm{Q}_{p} \pm 10 \%, \mathrm{Q}_{p} \pm 20 \%, \mathrm{Q}_{p} \pm 50 \%$ and $\mathrm{Q}_{p}+100 \%$. Afterwards, for each of the six cross-sections separately, a linear relation between both quantities (peak flow variation $\left(\Delta \mathrm{Q}_{p}\right)$ and peak water stage variation $\left.(\Delta \mathrm{d})\right)$ was found, the slope factor of which ( $a$ in $\Delta Q_{p}=a \cdot \Delta d+b$ ) quantified the variation of peak flow due to a one-unit variation of the peak water stage.

On the other hand, the hydrological model analysis assessed the influence of both the Curve Number and the antecedent soil moisture condition on the peak flow.

This was done by applying several times the hydrological model in two subbasins, representative of the six, with the following changes: 
Table 3. Results of the hydraulic and the hydrological modelling.

\begin{tabular}{lcccccc}
\hline & \multicolumn{2}{c}{ Sió } & \multicolumn{2}{c}{ Ondara } & \multicolumn{2}{c}{ Corb } \\
& Mont-roig & Agramunt & Cervera & Tàrrega & Guimerà & Ciutadilla \\
\hline Peak-flow $\left(\mathrm{m}^{3} \mathrm{~s}^{-1}\right)$ & 1120 & 1010 & 852 & 1190 & 410 & 580 \\
Specific peak flow $\left(\mathrm{m}^{3} \mathrm{~s}^{-1} \mathrm{~km}^{-2}\right)$ & 5.1 & 3.2 & 9.9 & 7.9 & 4.5 & 4.7 \\
Area-weighed rainfall over the basin $(\mathrm{mm})$ & 112 & - & 155 & 147 & 114 & 114 \\
Maximum rain intensity $\left(\mathrm{mm} \mathrm{h}^{-1}\right)$ & 56 & - & 70 & 67 & 61 & 61 \\
Surface runoff volume $\left(\mathrm{hm}^{3}\right)$ & 15.1 & - & 10.0 & 15.9 & 5.9 & 14.0 \\
Runoff coefficient $(\%)$ & 61 & - & 77 & 72 & 57 & 59 \\
Lag-time (h) & 4 & - & 2.5 & 3.5 & 3 & 3.5 \\
\hline
\end{tabular}

Table 4. Results of the sensitivity analyses on the hydraulic and the hydrological modelling.

\begin{tabular}{lcccc}
\hline Basin & $\begin{array}{c}\text { Sensitivity analysis on } \\
\text { the hydraulic modelling } \\
\text { Cross- } \\
\text { section }\end{array}$ & $\begin{array}{c}\text { Peak flow variation }(\%) \text { due to } \\
\text { an increase of } 1 \mathrm{~cm} \text { in the } \\
\text { maximum water level }\end{array}$ & $\begin{array}{c}\text { Peak flow variation (\%) due to } \\
\text { an increase of one unit in the } \\
\text { Curve Number }\end{array}$ & $\begin{array}{c}\text { Peak flow variation }(\%) \text { due to } \\
\text { a change in the antecedent } \\
\text { soil moisture condition from III to II }\end{array}$ \\
\hline \multirow{2}{*}{ Sió } & Mont-roig & 0.9 & 3.3 & -41 \\
\hline \multirow{2}{*}{ Ondara } & Agramunt & - & - & - \\
\hline \multirow{2}{*}{ Corb } & Tàrrega & 0.9 & 2.2 & -32 \\
\hline
\end{tabular}

1. Modifications in the Curve Number value around the calculated one $(\mathrm{CN}): \mathrm{CN} \pm 2$ units and $\mathrm{CN} \pm 4$ units.

2. Change of the antecedent soil moisture condition from III to II (which implied, actually, to modify the Curve Number value).

Then, linear functions were fitted to the data pairs (Curve Number, Peak flow variation), the slope factor of these linear functions ( $a$ in $\Delta Q_{p}=a \cdot \Delta C N+b$ ) quantifying the amount of peak flow variation per unity of Curve Number variation.

\section{Results and discussion}

As Table 3 and Fig. 9 show, the greatest peak flow occurred in Ondara at Tàrrega $\left(1190 \mathrm{~m}^{3} \mathrm{~s}^{-1}\right)$ and the greatest specific peak flow, in Ondara at Cervera $\left(9.9 \mathrm{~m}^{3} \mathrm{~s}^{-1} \mathrm{~km}^{-2}\right)$.

Besides, it is worth noting three area-dependent effects:

1. In the Sió, the peak flow decreased downstream - this may be explained by the spatial distribution of the rain, concentrated on the headwaters, and by the size of the basin.

2. In the Ondara, the specific peak flow increased dramatically upstream (i.e. as basin size decreased). Indeed, the specific peak flow of the Ondara at Cervera roughly doubled those of the neighbouring Sió and Corb.

3. In the Corb, the specific peak flow slightly increased downstream (i.e. as basin size increased) while it decreased in Sió and Ondara.

Since the hydrological behaviour was almost the same in the three basins (Curve Number of 85 and antecedent soil moisture condition III), the differences in specific peak flow (both, the differences in its magnitude and in its downstream evolution) between the Sió, the Ondara and the Corb may be explained by, on one hand, spatial differences in rainfall depths and intensities and, on the other hand, differences in streams' lengths and slopes and in the subbasins spatial arrangement, features that determine the rainfall-runoff transfer function (SCS's Unit Hydrograph) and the flow transit function (Munskingum-Cunge).

Actually, the specific peak flow value at Cervera was extraordinary: indeed, it exceeded - and the rest were similar to - the greatest specific peak flow in the systematic gauging data series in the Ebro basin: $5.4 \mathrm{~m}^{3} \mathrm{~s}^{-1} \mathrm{~km}^{-2}$ in Seco River at Oliete, in 1945, the second highest gauging record staying far behind: $3.3 \mathrm{~m}^{3} \mathrm{~s}^{-1} \mathrm{~km}^{-2}$ in Algars River at Horta de Sant Joan, in 1967 (López-Bustos, 1981). Cervera's value 

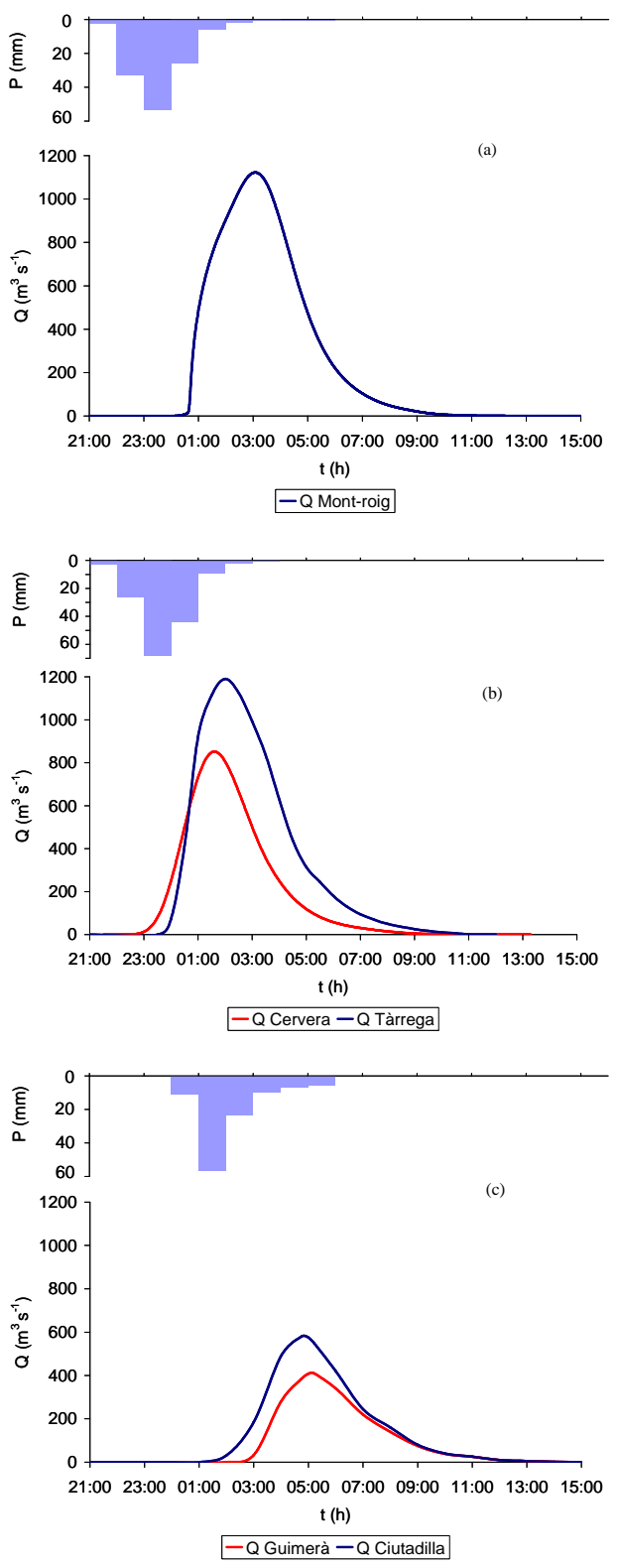

Fig. 9. Reconstructed hyetographs and hydrographs of Sió at Montroig (a), Ondara at Tàrrega and Cervera (b), and Corb at Guimerà and Ciutadilla (c).

even exceeded the specific peak flow of the non-systematic regional data series: $6 \mathrm{~m}^{3} \mathrm{~s}^{-1} \mathrm{~km}^{-2}$ (Thorndycraft et al., 2006). Nevertheless, the torrentiality indexes of the floods (i.e. the quotient of the peak flow divided by the annual mean flow) were around $10^{4}$ in the three basins, and can be judged as typical in Mediterranean rivers (Conacher and Sala, 1998).

Besides, lag-times were small $(2.5 \mathrm{~h}$ in Ondara at Cervera, $3 \mathrm{~h}$ in Corb at Guimerà, $4 \mathrm{~h}$ in Sió at Mont-roig); this agrees with the fast response of small catchments in a saturatedsoil condition and, along with the peak flows' magnitudes, explains the catastrophic effects of the event.
In any case, regarding the damages, Santa Tecla's floods can be classified as catastrophic; nevertheless, this event is not recorded in the principal Mediterranean data bases, or, if recorded, it is not classified as catastrophic (Barriendos et al., 2003; Barnolas and Llasat, 2007). The probable reason for this is that the affected zone is far from cities along larger rivers with extensive, long historical archives. More recently, using a different approach, Barriendos and Rodrigo (2006) classified Santa Tecla's floods as a Large Catastrophic Event (LCE) because it affected several basins.

On the other hand, the rainstorms required to generate such peak flows under a saturated-soil moisture condition are similar in Sió and Corb and higher in Ondara, according to the hydrological modelling results: the raindepths being 112 , 114 and $147 \mathrm{~mm}$, respectively and the maximum rain intensities being 56, 61 and $67 \mathrm{~mm} \mathrm{~h}^{-1}$ (Table 3); this, in spite of the same Curve Number, resulted in different runoff coefficients: 59\% in Corb at Ciutadilla, 61\% in Sió at Mont-roig and $77 \%$ in Ondara at Cervera.

If compared to a frequency analysis of 24-h maximum rainfall data series in Catalonia (Casas, 2005), the Santa Tecla's rainstorm, even though it had a duration of only eight hours, have had a return period of 500 years in Ondara's headwaters, and greater than 250 years in Sió's and Corb's headwaters.

In fact, Barriendos and Martín-Vide (1988) and Llasat et al. (2005) conclude that extreme floods frequency increased at both the beginning and the end of Little Ice Age (16th19th centuries); and indeed, Santa Tecla happened at the end of LIA.

The sensitivity analysis on the hydraulic modelling (Table 4) pointed out that the reconstruction of peak flows from flood marks is a sound approach, since, at least in our case, the uncertainty in the peak flow estimation was only around $1 \%$ per each centimetre of maximum water level error, which, in real field conditions, could arise up to $3-4 \mathrm{~cm}$.

Besides, the sensitivity analyses on the hydrological modelling brought out the huge influence of two steps of the procedure: the Curve Number and the antecedent soil moisture assignation. Indeed, an error of only one unit in the Curve Number, the determination of which is somewhat arbitrary and, thus, prone to a higher error, produced a variation in the peak flow of around 2-3\%. Similarly, the change from antecedent soil moisture condition III to II reduced the peak flow by $30-40 \%$.

However, there are many other sources of error not yet analyzed. For instance, the suspended-load concentrations, which were very high - about $12 \%$ in volume -, as could be estimated from some samples exceptionally preserved in unaltered cellars at Tàrrega. This fact points out that some characteristics of the flow's mechanics, modified by the suspended sediment and which could have had a crucial impact on hydraulic modelling, were not taken into account in this study. 


\section{Conclusions}

The hydraulic and hydrological reconstruction of Santa Tecla's rainstorm focused on the inland basins flowing into the Segre River, which are located in the northwestern quadrant of the probable affected area and cover about a $20 \%$ of it.

The results suggest that the rainfall was spatially heterogeneous, having a maximum in the central of the three studied basins (Ondara); besides, although the rainfall depths at the origin of this severe hydrological event don't seem to be particularly high or intense in a Mediterranean context, they actually are if compared to systematic rainfall data series of inland Catalonia.

Likewise, the calculated specific peak flows were greater than those recorded and modelled in similar-sized catchments in the Ebro basin. Certainly, the floods caused high-impact damages on the riverside towns. Moreover, the high soil moisture content before the event favoured the runoff production, multiplying the magnitude of Santa Tecla's floods.

However, antecedent soil moisture is not taken into account in the magnitude-frequency assessment of extraordinary floods, in which often only the 24-h rainfall is considered; this variable is all the more relevant since the sensitivity analysis revealed that an error in the antecedent soil moisture condition choice, a difficult one in lack of proper documentary information, can have, along with a wrong Curve Number determination, dramatic consequences in the peak flow estimation.

Therefore, a thorough exploration of local documentary sources is essential in flood reconstructions in order to find details which may be crucial in improving the modelling results and uncertainties.

And, although only the north-western part of the affected area could be studied so far, flood marks and documentary information of the event are available in other basins (Font Vella de Conesa, Francolí, Llobregós, Set). This fact makes possible a more extensive study of Santa Tecla's rainstorm, which would help to improve current understanding of it.

Actually, the ultimate objective of this research would be the improvement of the probability analysis of extreme hydrological events through the enlargement of the systematic rainfall data series with data from flood reconstruction.

Acknowledgements. The authors thank M.C. Llasat, G. Benito and another anonymous reviewer for their helpful comments which improved the text. They want to thank, as well, the Catalan Water Authority (ACA).

Edited by: M. C. Llasat

Reviewed by: G. Benito and another anonymous referee

\section{References}

Balasch, J. C., Tuset, J., and Ruiz-Bellet, J. L.: Reconstructing the 1874 Santa Tecla flash flood in the Ondara River (Ebro Basin, NE Spain), Adv. Geosci., 26, 45-48, 2010, http://www.adv-geosci.net/26/45/2010/.

Barnolas, M. and Llasat, M. C.: Metodología para el estudio de inundaciones históricas en España e implementación de un SIG en las cuencas del Ter, Segre y Llobregat. CEH-CEDEX, Monografías M-90, Ministerio de Fomento, Madrid, 264 pp., 2007.

Barriendos, M. and Martín-Vide, J.: Secular climatic oscillations as indicated by catastrophic floods in the Spanish Mediterranean coastal area (14th-19th centuries), Climatic Change, 38, 473491, 1988.

Barriendos, M., Coeur, D., Lang, M., Llasat, M. C., Naulet, R., Lemaitre, F., and Barrera, A.: Stationarity analysis of historical flood series in France and Spain (14th-20th centuries), Nat. Hazards Earth Syst. Sci., 3, 583-592, doi:10.5194/nhess-3-5832003, 2003.

Barriendos, M. and Rodrigo, F. S.: Study of historical flood events on Spanish rivers using documentary data, Hydrol. Sci. J., 51(5), 765-783, 2006.

Bayliss, A. C. and Reed, D. W.: The use of historical data in flood frequency estimation. CEH-NERC, Wallingford, UK, 87 pp., 2001.

Casas, M. C.: Análisis espacial y temporal de las lluvias extremas en Catalunya. Modelización y clasificación objetiva. PhD Thesis, University of Barcelona, 199 pp., 2005.

Confederación Hidrográfica del Ebro (CHE): Propuesta de Plan Hidrológico de la Cuenca del Ebro. Anexo 2: Aportaciones de las estaciones de aforo. Ministerio de Medio Ambiente, Medio Rural y Marino, Madrid, 10 pp., 1996.

Coma, M. T.: Les inundacions en el terme municipal de Tàrrega. Urtx, 2, 249-259, 1990.,

Conacher, A. and Sala, M.: Land degradation in Mediterranean environment of the World: nature and extent, causes and solutions, Wiley, Chichester, New York, 491 pp., 1998.

Iglesies, J.: L'aiguat de santa Tecla (23 de setembre de 1874), Episodis de la Història, 156, R. Dalmau, Barcelona, 62 pp., 1971.

Llasat, M. C., Barriendos, M., Barrera, T., and Rigo, T.: Floods in Catalonia (NE Spain) since the 14th Century. Climatological and meteorological aspects from historical documentary sources and old instrumental records, J. Hydrol., 313, 32-47, 2005.

López-Bustos, A.: Tomando el pulso a las grandes crecidas de los ríos peninsulares, Revista de Obras Públicas, 3190, 179-192, 1981.

Martin de Oliva, J.: Estudio de inundabilidad de la cuenca alta del río Corb. Reconstrucción del episodio de Santa Tecla (1874), Unpublished Master Thesis, ETSEA, University of Lleida, 228 pp., 2005.

Pleyán de Porta, J: Efemérides leridanas recogidas y ordenadas, Institut d'Estudis Ilerdencs, Lleida, España, 1945.

Remo, J. W. F. and Pinter, N.: Retro-modeling the Middle Mississipi River, J. Hydrol., 337, 421-435, 2007.

Salvadó, J.: Memoria de la inundación acaecida en la villa de Tárrega en la madrugada del día 23 de Setiembre del año 1874. Est. Tip. Ramirez, Barcelona, España, 86 pp., 1875.

Soil Conservation Service: Estimation of direct runoff from storm rainfall, Chapter 10, in Hydrology Natl. Eng. Handbook, Suppl. A, Section 4. USDA-SCS, Washington DC, 1985. 
Thorndycraft, V., Barriendos, M., Benito, G., Rico, M., and Casas, A.: The catastrophic floods of AD 1617 in Catalonia (northeast Spain) and their climatic context, Hydrol. Sci. J., 51(5), 899-912, 2006.

Tuset, J.: Reconstrucció de l'aiguat de Santa Tecla en el riu Ondara a Tàrrega a partir de limnimarques i restes de dipòsits decantats. Unpublished Master Thesis, ETSEA, University of Lleida, 224 pp., 2007.
US Army Corps of Engineers (USACE): HEC-RAS River Analysis System: Hydraulic Reference Manual, US Army Corps of Engineers Hydrologic Engineering Center, Davis, CA, 2008.

Xuclà, R. M.: Sopar al molí d'en Grau, Segarra, 773, 1-3, 1977. 